\title{
Association between geohelminth infections and physical growth in schoolchildren ${ }^{1}$
}

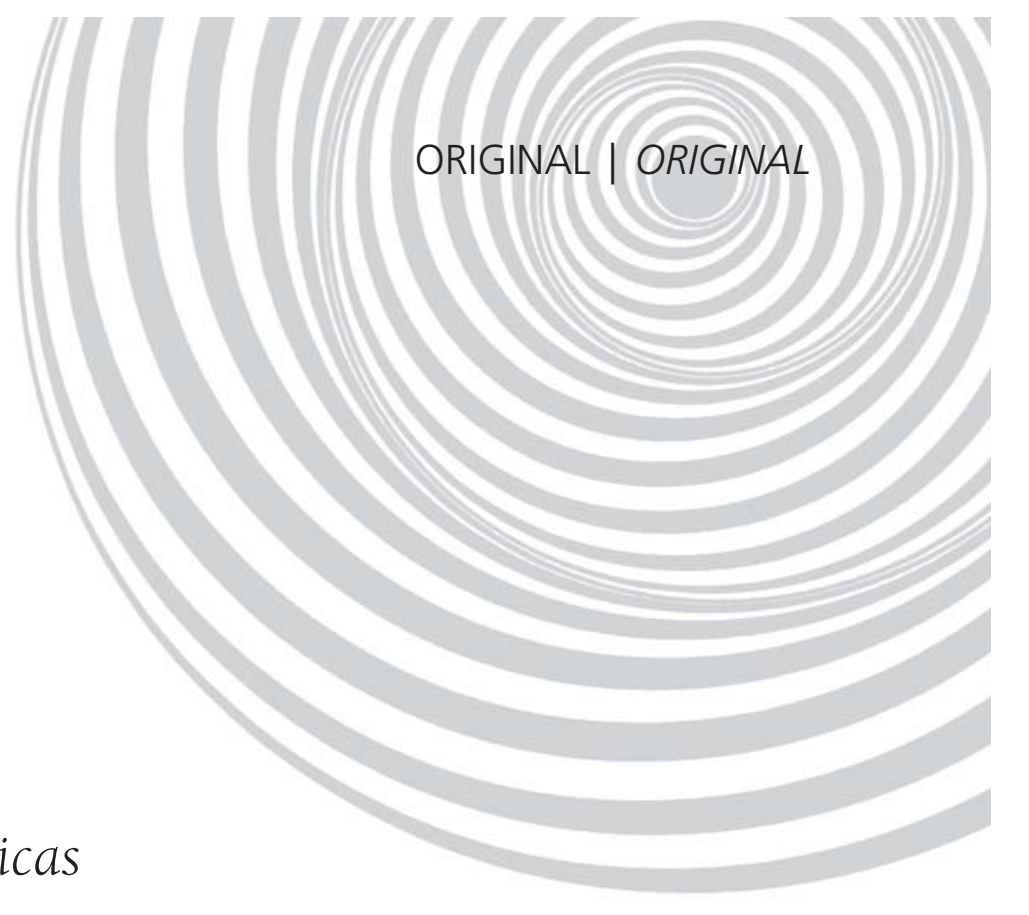

\author{
Associação entre infecções geohelminticas \\ e crescimento físico de escolares
}

Rita de Cássia Ribeiro SILVA²

Ana Marlucia Oliveira ASSIS²

A B S T R A C T

\section{Objective}

This study aims to assess the association between geohelminth infections and the physical growth of schoolchildren.

\section{Methods}

This is a cross-sectional study with the participation of 1861 children aging from 7 to 14 years who live in a municipality in the Southern region (Recôncavo) of the State of Bahia. The participants were submitted to anthropometric assessment and stool tests. Multiple logistic regression analysis was used as the statistical means to determine the association of interest.

\section{Results}

The risks of stunting were greater among boys with Ascaris lumbricoides (Odds ratio=1.79; confidence interval 95\%: 1.07-3.01), Trichuris trichiura (Odds ratio=2.26; confidence interval 95\%: 1.33-3.84) and ancylostomiasis (Odds ratio=2.18; confidence interval 95\%: 1.28-3.73) when compared with non-infected children. These results remained unchanged after adjustments for the location of the school, children's ages and other geohelminth infections.

\section{Conclusion}

These infections did not compromise girls' growth. These results emphasize the association between geohelminth infection and linear physical growth, indicating the need to implement preventive and curative measures that allow the quality of life of the children to improve since the repercussion that these parasites have on the nutritional status and health of this population is severe.

Indexing terms: Child. Growth. Helminthiasis. School health.

1 This study was sponsored by the Conselho Nacional de Desenvolvimento Científico e Tecnológico (CNPq), process no 503680-2003/6

2 Universidade Federal da Bahia, Escola de Nutrição. Av. Araújo Pinho, 32, Campus Universitário Canela, 40110-170, Salvador,

BA, Brasil. Correspondência para/Correspondence to: R.C.R. SILVA. E-mail: <rcrsilva@ufba.br>. 
394 | R.C.R. SILVA \& A.M.O. ASSIS

\section{RE S U M O}

\section{Objetivo}

Este estudo visa a avaliar a associação entre infecções geohelminticas e o crescimento físico de escolares.

\section{Métodos}

Trata-se de um estudo de corte transversal em que participaram 1851 indivíduos com idades entre 7 e 14 anos, residentes em um município do Recôncavo Sul do Estado da Bahia. Os indivíduos foram submetidos a avaliação antropométrica e a exame parasitológico de fezes. Utilizou-se a análise de regressão logística múltipla como técnica estatística para avaliar a associação de interesse.

\section{Resultados}

Os riscos de déficit do crescimento linear foram mais pronunciados entre os meninos portadores de infecção por Ascaris lumbricoides (Odds ratio=1,79; intervalo de confiança 95\% 1,07-3,01), Trichuris trichiuris (Odds ratio=2,26; intervalo de confiança 95\%: 1,33-3,84) e Ancilostomídeos (Odds ratio=2,18; intervalo de confiança 95\%: 1,28-3,73), quando comparados com os não infectados. Resultados que se mantiveram após os ajustamentos dos modelos pela área de localização da escola, idade das crianças e demais infecções geohelmínticas.

\section{Conclusão}

Não foi observado efeito comprometedor dessas infecções sobre o crescimento físico das meninas. Estes resultados ressaltam a associação entre infecção por geohelmintos e crescimento físico linear, indicando a necessidade de implantação de medidas preventivas e curativas que permitam a melhoria do nível de vida das crianças, considerando a grave repercussão que esses parasitas têm no estado nutricional e na saúde dessa população.

Termos de indexação: Crianças. Crescimento. Helmintíase. Saúde escolar.

\section{INTRODUCTION}

Intestinal parasites are an important health problem because of their broad distribution, high prevalences and their deleterious effects on the nutritional and immune conditions of the population, especially among those who live in tropical and subtropical areas, being even more relevant in undernourished populations ${ }^{1}$.

Ascariasis (roundworm), trichuriasis (whipworm) and ancylostomiasis (hookworm) are the most common geohelminth infections and are commonly found in areas where diseases, along with social, economic and cultural factors facilitate their occurrence. It is estimated that roughly one billion people are infected by Ascaris lumbricoides, 500 million by Trichuris trichiura and 900 million by ancylostoma hookworms ${ }^{1}$.

The epidemiological importance of these geohelminths lies especially on their negative effects on nutritional status ${ }^{2}$ and impairment of immune functions ${ }^{3}$. These infections have also been associated with reduced ability to learn and cognition of schoolchildren ${ }^{4}$.
Reduced food intake due to parasitic diseases is a vital factor for weight loss and/or stunting in children and adolescents ${ }^{5}$. This reduced food intake is attributed to many physiological changes and epigastric symptoms produced mainly by geohelminth infections, many of which are present in the upper portion of the small intestine ${ }^{6}$. There are evidences that these changes are associated with infection intensity ${ }^{6}$.

Some factors that affect growth in preschool children are well documented; however there are important gaps in knowledge when the target population is represented by school-aged children. It is known that parasitic diseases, together with adverse life conditions, health and nutrition, stand out as important factors that compromise the physical growth of this population?

Thus, the objective of this study is to assess the association between geohelminth infections and growth of elementary and middle school children enrolled in public and private schools of Mutuípe, a city in the southern area of the State of Bahia. 


\section{METHODS}

This is a cross-sectional study with elementary and middle school students who live in the city of Mutuípe, Bahia, located $235 \mathrm{~km}$ away from Salvador in the Southern Recôncavo region of the State of Bahia. The municipality has a population of 20,462 inhabitants, where 11,478 $(56 \%)$ live in the rural area and 8,984 (44\%) live in the urban area. Rural activities predominate in the municipality, where the main crops are cacao, banana, manioc, beans and corn ${ }^{8}$. Economically, the municipality ranks 146 th among the 417 municipalities of the state according to the Economic Development Index (IDE) of the Superintendence of Economic Studies; socially, the municipality ranks 135 th according to the Social Development Index (IDS) 9 .

The study consisted of children of both genders aging from 7 to 14 years enrolled in public and private elementary and middle schools of the municipality. Of the 4,200 students enrolled, 3,144 participated in the anthropometric assessment. All students aging 15 years or more were excluded, as well as those with physical traumas who were immobilized when the anthropometric measurements took place or students who, for some reason, could not be assessed. Children whose birth date was unknown were also excluded. Of the children eligible for the study, 1,851 students completed all the procedures defined in the research protocol. Roughly $40 \%$ of the cases were lost due to many reasons; embarrassment to turn in a stool sample was reported by most of the students. Still, the number of children was enough to assess an association between geohelminth infections and linear growth, with a statistical power of (1- $\beta$ ) of $98 \%$ and a significance level of $5 \%$.

Collection of stool samples was done by giving all students a plastic, lidded, labeled and numbered recipient. The diagnosis and helminth egg count in the stools was done by the Kato-Katz method $^{10}$. An estimated number of helminth eggs (Ascaris lumbricoides, Trichuris trichiura and ancylostoma hookworm) per gram of feces was obtained by multiplying the number of eggs found in each Kato slide by the constant $24^{10}$. The intensity degree (mild, moderate and severe) was established according to the WHO's (World Health Organization) recommendation?.

Weight was determined with the microelectronic scale brand Filizola, model E-150/ 3P. Height was determined to the nearest millimeter by a stadiometer brand Leicester Height Measure, according to the procedures recommended by Lohman ${ }^{11}$. Body weight and height were measured twice by two independent researchers who recorded the results in separate forms. A maximum variation of $0.5 \mathrm{~cm}$ for height and $100 \mathrm{~g}$ for weight were allowed between the two measurements. A third measurement was done if the difference between the first two was greater than the variation allowed. The mean of the two closest values was considered the final mean ${ }^{11}$.

The birth date of each child was obtained from his/her enrollment records supplied by the City Department of Education.

Z-scores for the height-for-age indicator were calculated using the Epi info - Epinut anthropometric module. The growth standard developed by the National Center for Health Statistics (NCHS) ${ }^{12}$ was used according to the WHO's recommendations ${ }^{13}$. The height-for-age indicator was used to determine stunting.

Children were considered stunted when their height-for-age was below two negative standard deviations from the mean value of the NCHS reference population ${ }^{12}$.

The study was submitted to the Ethics Committee of the Climério de Oliveira Maternity, who reviewed the study protocol and issued a favorable opinion under protocol number 77/2005. After giving detailed information about the study to the children's caregivers, a free and informed consent form was obtained from them. The children could only participate in the study if their caregivers had signed the Free and Informed Consent Form (FICF). 
In order to assess the distribution homogeneity of geohelminth infections (infection by $A$. Lumbricoides, T. Trichiura and ancylostoma hookworm) according to gender, age, school location and anthropometric status (assessed by the height-for-age indicator), the Pearson's chisquare $\chi^{2}$ test was used. Multivariate logistic regression was used to assess the associations of interest. The presence of confounding and interaction was explored based on the logistic regression models, through backward procedure ${ }^{14}$. We began with a saturated model containing all potential effect-modifying variables and their respective product terms, besides the confounding variables ${ }^{14}$. The effect-modifying variables are those that present statistically significant results $(p<0.05)$ according to the maximum likelihood ratio test. The confounding variables were those that, when taken out of the model, caused a change equal to or greater than $20 \%$ in the specific measurement of the association between geohelminth infection and stunting.

The variables of the model were chosen based on the existing knowledge found in the literature. Statistical inference was based on confidence intervals of $95 \%$. The software SPSS v. 11 was used to process and analyze data.
The dependent variable of the study was represented by the height-for-age indicator (normal=0, stunting=1). Geohelminth infections with A. lumbricoides (not infected=0, infected=1), T. trichiura (not infected $=0$, infected $=1$ ) and ancylostoma hookworm (not infected=0, infected $=1$ ) were the main independent variables in each of the 3 models presented. Exploratory variables were also included, such as gender (female $=1$, male $=0$ ), age ( $>10$ years $=0, \leq 10$ years $=0$ ) and location of the school as indicator of the socioeconomic conditions (urban=0, rural=1).

\section{RE S U L T S}

The studied sample consisted of $48.3 \%$ males and $38.7 \%$ younger than 10 years of age. Stunting was found in $6.4 \%$ of the children. The percentages of children infected by $A$. lumbricoides, T. trichiura and ancylostoma hookworm were respectively $26.9 \%, 21.8 \%$ and $13.3 \%$. A little more than half of the children $(53.7 \%)$ studied in schools located in rural areas. When the distribution characteristics of the sample was assessed according to geohelminth infections, only $T$. trichiura infection was not associated with the location of the school $(p=-0.55)$ (Table 1).

Table 1. Distribution of the studied population characteristics according to infections with A. lumbricoides, T. trichiura and ancylostoma hookworm in elementary and middle school children enrolled in public and private schools of Mutuipe (BA), 2006.

\begin{tabular}{|c|c|c|c|c|c|c|c|c|c|c|}
\hline \multirow[t]{2}{*}{ Population characteristics } & \multirow[t]{2}{*}{$\mathrm{n}$} & \multicolumn{3}{|c|}{$\begin{array}{l}\text { Postitive for Arcaris } \\
\text { lumbricoides }\end{array}$} & \multicolumn{3}{|c|}{$\begin{array}{c}\text { Postitive for Trichuris } \\
\text { trichiura }\end{array}$} & \multicolumn{3}{|c|}{$\begin{array}{c}\text { Postitive for Ancylostoma } \\
\text { hookworm }\end{array}$} \\
\hline & & $n$ & $\%$ & p-value & $\mathrm{n}$ & $\%$ & $p$-value & $\mathrm{n}$ & $\%$ & p-value \\
\hline \multicolumn{11}{|l|}{ Gender } \\
\hline Male & 895 & 260 & 29,1 & 0,070 & 212 & 23,7 & 0,060 & 139 & 15,5 & 0,004 \\
\hline Female & 956 & 242 & 25,3 & & 192 & 20,2 & & 105 & 11,0 & \\
\hline \multicolumn{11}{|l|}{ Age } \\
\hline 7 to 10 & 717 & 169 & 23,6 & 0,006 & 142 & 19,8 & 0,080 & 74 & 10,3 & 0,004 \\
\hline 10 to 14 & 1134 & 333 & 29,4 & & 263 & 23,2 & & 170 & 15,0 & \\
\hline \multicolumn{11}{|l|}{ School location } \\
\hline Urban & 856 & 181 & 21,1 & 0,000 & 182 & 21,3 & 0,050 & 70 & 8,2 & 0,000 \\
\hline Rural & 995 & 321 & 32,3 & & 223 & 22,4 & & 174 & 17,5 & \\
\hline \multicolumn{11}{|l|}{ Height-for-age (in Z-escore) } \\
\hline Stunted (-2DP) & 119 & 53 & 44,5 & 0,000 & 47 & 39,5 & 0,000 & 31 & 26,1 & 0,000 \\
\hline Normal ( $\geq-2 D P)$ & 1732 & 449 & 25,9 & & 358 & 20,7 & & 213 & 12,3 & \\
\hline
\end{tabular}


The results of multivariate logistic regression for the association between stunting and geohelminth infection, stratified by gender, are presented in Table 2. Gender stratification was due to its modifying effect of the main associations found in the models for $A$. lumbricoides $(p<0.001)$, T. trichiura $(p<0.001)$ and ancylostoma hookworm $(p<0.001)$. In these adjusted models, the boys infected with $A$. lumbricoides (OR=1.79; $\mathrm{Cl} 95 \%$ : 1.07-3.01), T. trichiura ( $\mathrm{OR}=2.26 ; \mathrm{Cl} 95 \%$ : 1.33-3.84) and ancylostoma hookworm (OR=2.18; Cl 95\%: 1.28-3.73) were at higher risk of stunting. A significant association between geohelminth infections and stunting was not found among girls.

Figure 1 shows the data regarding infection intensity by geohelminth species. Mild $A$. lumbricoides, T. trichiura and ancylostoma hookworm infections were found in 12.7\%, 21.9\% and $3.5 \%$ of the sample, respectively. Moderate and severe $A$. lumbricoides, T. trichiura and ancylostoma hookworm infections were found in $13.6 \%, 3.7 \%$ and $0.4 \%$ of the sample, respectively.

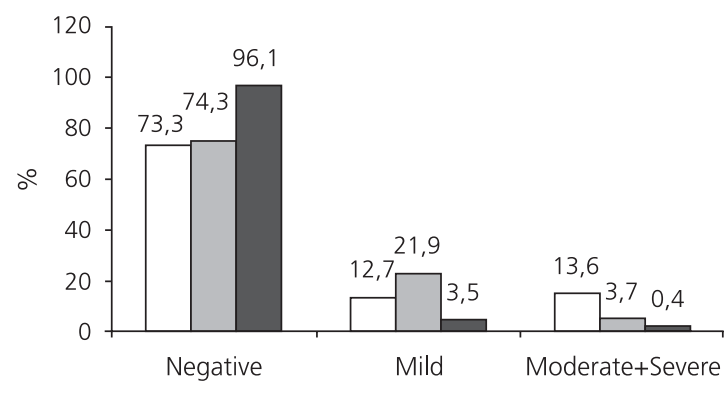

$\square$ A. lumbricoides $\square$ T. Trichuris $\square$ Ancylostoma hookworm

Figure 1. Infection intensity according to geohelminth infection in elementary and middle school children enrolled in public and private schools of Mutuípe (BA), 2006.

\section{DISCUSSION}

The results of this study indicate that infection with A. lumbricoides, T. Trichiura and ancylostoma hookworm compromise boys' growth. The differences observed between the genders, unfavorable for boys, may be explained by the higher rate of geohelminth infection in this group. It is possible that boys are more exposed to the outdoor environment during leisure and labor activities. Probably, these environments are

Table 2. Odds Ratio (OR) and confidence intervals (C195\%) of the association between geohelminth infections (A. lumbricoides, $T$. trichiura and Ancylostoma hookworm) and stunting in elementary and middle school children enrolled in public and private schools of Mutuipe (BA), 2006.

\begin{tabular}{|c|c|c|c|c|c|}
\hline Geohelminth/gender & Infections & $\mathrm{OR}_{\text {gross }}$ & $\mathrm{C} 195 \%$ & ${ }^{*} O R_{\text {ajusted }}$ & $\mathrm{C} 195 \%$ \\
\hline \multicolumn{6}{|l|}{ A. lumbricoides } \\
\hline \multirow[t]{2}{*}{ Male } & Negative & 1,00 & & 1,00 & \\
\hline & Positive & 2,77 & $1,72-4,45$ & 1,79 & $1,07-3,01$ \\
\hline \multirow[t]{2}{*}{ Female } & Negative & 1,00 & & 1,00 & \\
\hline & Positive & 1,50 & $0,77-2,90$ & 1,11 & $0,53-2,29$ \\
\hline \multicolumn{6}{|l|}{ T. trichuris } \\
\hline \multirow[t]{2}{*}{ Male } & Negative & 1,00 & & 1,00 & \\
\hline & Positive & 3,01 & $1,87-4,86$ & 2,26 & $1,33-3,84$ \\
\hline \multirow[t]{2}{*}{ Female } & Negative & 1,00 & & 1,00 & \\
\hline & Positive & 1,62 & $0,83-3,22$ & 1,44 & $0,68-3,08$ \\
\hline \multicolumn{6}{|c|}{ Ancylostoma hookworm } \\
\hline \multirow[t]{2}{*}{ Male } & Negative & 1,00 & & 1,00 & \\
\hline & Positive & 2,57 & $1,52-4,36$ & 2,18 & $1,28-3,73$ \\
\hline \multirow[t]{2}{*}{ Female } & Negative & 1,00 & & 1,00 & \\
\hline & Positive & 1,98 & $0,89-4,40$ & 1,43 & $0,61-3,37$ \\
\hline
\end{tabular}

*OR: Odds Ratio adjusted for age, school location and other geohelminth infections. 
contaminated by eggs and larvae of intestinal helminths because of improper disposal of human wastes and sewers, contributing for parasite dissemination.

The present findings agree with the current knowledge regarding infection and growth. The negative impact of parasitic infections on growth is observed in many studies that use different measurements and indicators of anthropometric status, such as weight ${ }^{15-18}$, height ${ }^{19-21}$ weight-for$\operatorname{age}^{16,22}$, height-for-age ${ }^{16}$ and weight-forheight ${ }^{17,22-24}$. For these authors, infections act negatively over the genetic growth potential of children and adolescents, keeping them from reaching full somatic growth. Studies published so far indicate that parasitic infections compose the range of entities that limit the growth of these population groups and explanations for their pathophysiological mechanisms can be found in the infection and nutrition axes.

Another situation to be considered is the infection load: negative impact increases as infection load increases ${ }^{6}$. However, in this study, even mild and moderate parasitic loads had an unquestionable impact on growth. Most of the students in this study had a mild parasitic load as shown in Figure 1. The percentages of children with mild $A$. lumbricoides, T. trichiura and ancylostoma hookworm were $12.7 \%, 21.9 \%$ and $3.5 \%$, respectively. It is known that high prevalences of infectious diseases with a symptomatic or subclinical nature contribute to stunting already in the first years of life ${ }^{25}$.

Although the information on the growth pattern of schoolchildren in developing countries is scarce, it is estimated that parasitic diseases, even subclinical infections, continue to have an important role in the etiology of stunting in this phase of life ${ }^{2}$. Stunting can worsen with adverse life conditions and repeated infectious episodes throughout successive life phases, making the child reach the beginning of pubescence with a very low stature; finally, when the individual finishes growing, he or she will be below the normal standards of the reference population ${ }^{2}$.
Furthermore, when infection coincides with adolescence, especially when it happens when the child grows most (pubescence), the maximum response potential of bone, muscle and fat tissue growth can be reduced because of changes in the metabolic processes that involve nutrients and because of the hormonal influences associated with growth ${ }^{26}$.

The limitations of this study consist mainly of selection bias, common to studies of observational nature. In this study, infected subjects were identified by a single stool test. If each individual had been tested twice or three times, the number of infected individuals would likely be greater. Thus, the estimations of effect found can be underestimated.

The findings of this study show the need to implement preventive and curative measures that allow the quality of life of these children to improve. The repercussion that these parasites have on the nutritional status and health of this population is considered severe.

\section{ACKNOWLEDGMENT}

The authors thank Professor Sandra Maria Santos Chaves, coordinator of the project called "Support to the development of the municipal system of food and nutrition security of Mutuípe, Bahia" for accepting the proposal that gave rise to this article.

\section{COLABHORATES}

R.C.R. SILVA helped conceive the study, analyze data, interpret the results and write the article. A.M.O. ASSIS helped conceive the study, interpret the results and write the article.

\section{REFERE N CES}

1. Prevention and control of intestinal parasitic infections. Report of a WHO Expert Committee. World Health Organ Tech Rep Ser. 1987; 749:1-86.

2. Allen LH. Nutritional influences on linear growth: a general review. Eur J Clin Nutr. 1994; 48(Suppl 1):S75-89. 
3. Beisel WR. Effects of infection on nutritional status and immunity. Fed Proc. 1980; 39(13):3105-8

4. Grantham-McGregor SM. Assessments of the effects of nutrition on mental development and behavior in Jamaican studies. Am J Clin Nutr. 1993; 57(2 Suppl):303S-9S.

5. Martorell R, Yarbrough C, Yarbrough S, Klein RE. The impact of ordinary illnesses on the dietary intakes of malnourished children. Am J Clin Nutr. 1980; 33(2):345-50.

6. Hall A. Intestinal parasitic worms and the growth of children. Trans R Soc Trop Med Hyg. 1993; 87(3):241-2.

7. Musgrove P. Investing in health: the 1993 World Development Report of the World Bank. Bull Pan Am Health Organ. 1993; 27(3):284-6.

8. Assis AMO, Portela ML, Santos SS, Pinheiro SMC. Diagnóstico de saúde e nutrição da população de Mutuípe. Salvador: EDUFBA; 2002.

9. Superintendência de Estudos Econômicos-SEl/BA. Índice de desenvolvimento econômico e social dos municípios baianos: Salvador; 2002.

10. Katz N, Chaves A, Pellegrino J. A simple device for quantitative stool thick-smear technique in Schistosomiasis mansoni. Rev Inst Med Trop São Paulo. 1972; 14(6):397-400.

11. Lohman TGRA. Anthropometric standardization reference manual. Champaign, Illinois: Human Kinetics; 1988.

12. Hamill PV, Drizd TA, Johnson CL, Reed RB, Roche AF, Moore WM. Physical growth: National Center for Health Statistics percentiles. Am J Clin Nutr. 1979; 32(3):607-29.

13. Physical status: the use and interpretation of anthropometry. Report of a WHO Expert Committee. World Health Organ Tech Rep Ser. 1995; 854:1-452.

14. Keinbaum DG, Kupper LL, Lawrence L, Morgenstern H. Epidemiologic reasearch: principles and quantitative methods. New York: Van Nostrand Reinhold; 1982. p.529.

15. Stephenson LS, Crompton DW, Latham MC, Schulpen TW, Nesheim MC, Jansen AA. Relationships between Ascaris infection and growth of malnourished preschool children in Kenya. Am J Clin Nutr. 1980; 33(5):1165-72.

16. Stephenson LS, Kinoti SN, Latham MC, Kurz KM, Kyobe J. Single dose metrifonate or praziquantel treatment in Kenyan children. I. Effects on Schistosoma haematobium, hookworm, hemoglobin levels, splenomegaly, and hepatomegaly. Am J Trop Med Hyg. 1989; 41(4):436-44.
17. Adams EJ, Stephenson LS, Latham MC, Kinoti SN. Physical activity and growth of Kenyan school children with hookworm, Trichuris trichiura and Ascaris lumbricoides infections are improved after treatment with albendazole. J Nutr. 1994; 124(8): 1199-206.

18. Watkins WE, Pollitt E. Effect of removing Ascaris on the growth of Guatemalan schoolchildren. Pediatrics. 1996; 97(6 Pt 1):871-6.

19. Hadju V, Stephenson LS, Abadi K, Mohammed HO, Bowman DD, Parker RS. Improvements in appetite and growth in helminth-infected schoolboys three and seven weeks after a single dose of pyrantel pamoate. Parasitology. 1996; 113(Pt 5):497-504.

20. Hadju V, Satriono AK, Stephenson LS. Relationships between soil-transmitted helminthiases and growth in urban slum schoolchildren in Ujung Pandang, Indonesia. Int J Food Sci Nutr. 1997; 48(2):85-93.

21. Kightlinger LK, Seed JR, Kightlinger MB. Ascaris lumbricoides aggregation in relation to child growth status, delayed cutaneous hypersensitivity, and plant anthelmintic use in Madagascar. J Parasitol. 1996; 82(1):25-33.

22. Stephenson LS, Latham MC, Adams EJ, Kinoti SN, Pertet $A$. Weight gain of Kenyan school children infected with hookworm, Trichuris trichiura and Ascaris lumbricoides is improved following onceor twice-yearly treatment with albendazole. J Nutr. 1993; 123(4):656-65.

23. Stephenson LS, Latham MC, Kurz KM, Kinoti SN, Brigham $\mathrm{H}$. Treatment with a single dose of albendazole improves growth of Kenyan schoolchildren with hookworm, Trichuris trichiura, and Ascaris lumbricoides infections. Am J Trop Med Hyg. 1989; 41(1):78-87.

24. Stephenson LS, Latham MC, Adams EJ, Kinoti SN, Pertet A. Physical fitness, growth and appetite of Kenyan school boys with hookworm, Trichuris trichiura and Ascaris lumbricoides infections are improved four months after a single dose of albendazole. J Nutr. 1993; 123(6):1036-46.

25. Saldiva SR, Silveira AS, Philippi ST, Torres DM, Mangini AC, Dias RM, et al. Ascaris-Trichuris association and malnutrition in Brazilian children. Paediatr Perinat Epidemiol. 1999; 13(1):89-98.

26. Solomons NW. Pathways to the impairment of human nutritional status by gastrointestinal pathogens. Parasitology. 1993; 107(Suppl): S19-35. 